Pengaruh Kepemilikan Keluarga Dan Good Corporate Governance...

\title{
PENGARUH KEPEMILIKAN KELUARGA DAN GOOD CORPORATE GOVERNANCE TERHADAP KUALITAS LABA DAN KINERJA PERUSAHAAN
}

\author{
Anna Mathova, Halim Dedy Perdana, Isna Putri Rahmawati \\ (Program Studi Akuntansi Universitas Sebelas Maret Surakarta)
}

\begin{abstract}
Abstrak
This research is purposed to find out the effect of family ownership and Good Corporate Governance toward the earning quality and firm performance of the company listed in Indonesian Stock Exchange from 2012 up to 2014. The sample of this research is using 153 companies for the earning quality model and 137 companies for firm performance model in Indonesia from 2012 up to 2014. The sampling is done using purposive sampling method. The analysis method used is multiple linear regression analysis method using SPSS version 21.00. The result of the regression testing of earning quality model shows that only debt ratio influent the earning quality, while family ownership, institutional ownership, independent commissioner, type audit and payout ratio do not. The test for the firm performance shows that the institutional ownership, independent commissioner, type audit and payout ratio are influencing the firm performance while the family ownership and debt ratio are not.
\end{abstract}

Keywords: Family ownership, Good Corporate Governance (GCG), earning quality, and firm performance.

\section{LATAR BELAKANG}

Bisnis keluarga merupakan bentuk bisnis tertua dan paling dominan di dunia organisasi bisnis. Bisnis keluarga tidak hanya berkisar pada perusahaan kecil dengan sektor industri tertentu, tetapi perusahaan menengah dan besar serta beroperasi di berbagai sektor industri. Di banyak negara, bisnis keluarga mewakili lebih dari 70 persen bisnis secara keseluruhan dan memainkan peran kunci dalam pertumbuhan ekonomi dan tenaga kerja (McGee, 2013).

Perusahaan yang memiliki konsentrasi kepemilikan keluarga yang mayoritas diyakini memiliki kinerja perusahaan yang jauh lebih baik dari perusahaan yang bukan berbasis kepemilikan keluarga (Martinez dan Stohr, 2005). Hal ini disebabkan karena perusahaan yang dikendalikan oleh keluarga mampu memprofesionalkan manajemen dan tata kelola mereka ketika merasa mendapat tekanan pengawasan pasar dan saat harus 
bertanggung jawab kepada pemegang saham minoritas. Mereka mengatasi sebagian besar kelemahan tradisional mereka dan mengambil keuntungan dari kekuatannya untuk berhasil.

Akan tetapi, kinerja perusahaan keluarga yang melesat sangat baik dengan keuntungan saham yang terbaik hanya terjadi pada tahun-tahun awal perusahaan didirikan, kemudian kinerjanya akan melandai pada generasi selanjutnya. Hal ini dibuktikan dengan riset CSRI yang menyimpulkan bahwa 50 persen perusahaan keluarga berhasil melewati masa transisi peralihan ke generasi kedua dengan sukses. Akan tetapi, pada masa peralihan berikutnya, hanya 22 persen perusahaan keluarga yang mampu bertahan dan berkurang menjadi 10 persen pada transisi berikutnya.

Andayani et al. (2014) meneliti mengenai pengaruh kepemilikan keluarga terhadap kinerja dan kualitas laba perusahaan berdasarkan teori Stewardship. Hasil penelitian ini menunjukkan bahwa kepemilikan keluarga memiliki pengaruh yang positif terhadap kinerja perusahaan. Selain itu, penilitian ini juga menunjukkan bahwa manajer terbukti tidak bertindak oportunis sehingga kualitas informasi keuangannya menjadi baik dan dapat dipercaya. Perbedaan penelitian tersebut terhadap penelitian sekarang adalah penelitian sekarang menggunakan variabel lain yang dihubungkan dengan kinerja perusahaan yaitu Good Corporate Governance yang mana variabel ini belum digunakan dalam penelitian tersebut.

Al-Ghamdi dan Rhodes (2015) meneliti tentang Kepemilikan Keluarga, Corporate Governance dan Kinerja Perusahaan. Hasil dari penelitian ini menunjukkan bahwa konsentrasi kepemilikan tidak memiliki hubungan yang sistematis dengan kinerja perusahaan yang diproksikan dengan ROA. Konsentrasi kepemilikan di perusahaan keluarga memiliki hubungan yang positif dengan kinerja perusahaan yang diproksikan dengan Tobin's Q. Selain itu, penelitian ini juga menunjukkan bahwa ada hubungan antara kinerja dan ukuran dewan komisaris di perusahaan yang mendukung suatu pandangan bahwa non dualitas penting untuk kinerja di perusahaan keluarga.

Renato Giovannini (2010) dalam penelitiannya menyebutkan bahwa pada dasarnya, terdapat dapak substansial yang negatif ketika kontrol perusahaan terkonsentrasi pada keluarga. Hal ini menyiratkan bahwa kekuasaaan akan semakin terkontrol hanya pada keluarga sehingga struktur manajemen (managerialization) akan terbatas, nepotisme, dan 
Pengaruh Kepemilikan Keluarga Dan Good Corporate Governance...

kontrol yang ketat seringkali menghambat pertumbuhan, dan tentu akan memberikan hasil kinerja manajemen yang kurang memuaskan.

Jika ditinjau teori stewardship, maka anggota keluarga bersedia untuk menempatkan kepentingan pribadi untuk kepentingan perusahaan sehingga dapat menghasilkan kualitas laba yang baik. Selain itu, untuk meminimalisir adanya konflik keagenan yang mungkin terjadi akibat sifat oportunistik manajemen dapat diatasi dengan tata kelola perusahaan yang baik. Akan tetapi, penerapan GCG yang diterapkan dalam perusahaan publik pada umumnya akan memberikan dampak pada perusahaan keluarga yang lebih kompleks. Berdasarkan hal tersebut, peneliti merumuskan masalah sebagai berikut: (1) Apakah kepemilikan keluarga berpengaruh positif terhadap kualitas laba dan kinerja perusahaan, (2) Apakah praktik GCG berpengaruh terhadap kualitas laba dan kinerja perusahaan.

\section{LANDASAN TEORI DAN PENGEMBANGAN HIPOTESIS Teori Keagenan (Agency Theory)}

Teori keagenan mendeskripsikan hubungan antara pemegang saham (shareholders) sebagai prinsipal dan manajemen sebagai agen. Dalam teori ini, baik prinsipal maupun agen dianggap sebagai orang ekonomi rasional yang termotivasi untuk kepetingan pribadi, tapi mereka kesulitan untuk membedakan penghargaan atas preferensi, kepercayaan, da informasi (Raharjo, 2007).

Jensen dan Meckling (1976) menjelaskan hubungan keagenan sebagai "agency relationship as a contract under which one or more person (the principals) engage another person (the agent) to perform some service on their behalf which involves delegating some decision making authority to the agent".

Para pemilik perusahaan berharap manajemen mampu bertindak sesuai dengan kepentingan mereka dan mampu menggunakan sumber daya yang dipercayakan kepadanya seoptimal mungkin. Sehingga, pemilik berharap bahwa manajemen mampu menyejahterakan kepentingan mereka baik dalam jangka pendek ataupun panjang.

Masalah keagenan yang kerap kali terjadi apabila bagian kepemilikan manajer atas saham perusahaan kurang dari seratus persen (Masdupi, 2005). Dengan proporsi kepemilikan yang hanya sebagian dari perusahaan membuat manajer cenderung bertindak untuk kepentingan pribadi dan bukan untuk memaksimumkan perusahaan. Inilah yang 
nantinya akan menyebabkan biaya keagenan (agency cost). Jensen dan Meckling (1976) mendefinisikan agency cost sebagai jumlah dari biaya yang dikeluarkan prinsipal untuk melakukan pengawasan terhadap agen.

Salah satu cara yang dilakukan untuk meminimalisir terjadinya masalah keagenan ini adalah dengan kepemilikan keluarga dan penerapan good corporate governance. Adanya keluarga dalam susunan pemegang saham yang cukup dominan dianggap dapat menghasilkan kinerja yang lebih efisien dibandingkan perusahaan dengan kepemilikan publik (Astuti et al., 2015). Konsentrasi kepemilikan yang tinggi akan membuat fungsi pengawasan dewan menjadi kurang relevan sehingga meminimalkan masalah keagenan (Singh et al., 2015). Penerapan GCG juga nantinya diharapkan akan menekan sikap oportunistik manajer sehingga dapat meningkatkan kualitas laba dan kinerja dari perusahaan.

\section{Teori Stewardship}

Teori stewardship berakar dari ilmu psikologi dan sosiologi yang menjelaskan situasi dimana manajer sebagai steward bertindak sesuai keinginan pemilik (Raharjo, 2007). Dalam teori ini, manajer akan bertindak sesuai dengan kepentingan bersama. Ketika kepentingan antara manajer dan pemilik tidak sama, maka manajer akan berusaha untuk bekerja sama karena menurutnya cara seperti ini lebih rasional untuk mencapai tujuan dari organisasi. Teori stewardship mengasumsikan hubungan yang kuat antara kesuksesan organisasi dengan kepuasan pemilik (Raharjo, 2007).

Perusahaan keluarga dapat mempengaruhi kualitas laba akuntansi dan kinerja perusahaan dalam dua acara, yaitu dengan menguntungkan diri sendiri atau dengan keselarasan. Penelitian Andayani et al. (2014) menunjukkan bahwa dalam perusahaan yang dikelola oleh keluarga, keuntungan tidak dikelola secara oportunistik dan keuntungan memiliki kualitas yang tinggi. Hal ini menujukkan bahwa hal tersebut sejalan dengan argumen dalam teori stewardship yang menjelaskan bahwa anggota keluarga bersedia untuk menempatkan kepentingan pribadi untuk kepentingan perusahaan sehingga dapat menghasilkan kualitas laba yang baik. 
Pengaruh Kepemilikan Keluarga Dan Good Corporate Governance...

\section{Pengembangan Hipotesisi}

\section{Kepemilikan Keluarga}

Berdasarkan teori stewardship, pada perusahaan keluarga keuntungan perusahaan tidak dikelola secara oportunis dan pengendali berkomitmen untuk tidak melawan pemegang saham minoritas. Komitmen untuk mengedepakan kepentingan bersama di atas kepentingan pribadi akan membuat pengelola berusaha semaksimal mungkin untuk kemajuan perusahaan. Oleh karena itu, berdasarkan pada teori stewardship, maka hipotesis yang diambil adalah :

$$
\begin{array}{ll}
H 1 a & : \text { Kepemilikan keluarga berpengaruh positif terhadap kualitas laba } \\
H 1 b & : \text { Kepemilikan keluarga berpengaruh positif terhadap kinerja } \\
& \text { perusahaan }
\end{array}
$$

\section{Kepemilikan Institusi}

Mekanisme pengendalian eksternal penting yang semakin mempengaruhi tata kelola perusahaan di seluruh dunia adalah munculnya investor institusi sebagai pemilik ekuitas (Wu dan Johan, 2006). Adanya keberadaan investor institusi dianggap akan mampu mengoptimalkan pengawasan terhadap kinerja manajemen dengan memonitoring setiap keputusan yang diambil oleh manajemen selaku pengelola perusahaan (Wiranata dan Nugrahanti, 2013). Pada penelitian terdahulu yang dilakukan oleh Nirosha Hewa Welallage dan Stuart Locke (2011) menjelaskan bahwa hipotesis pengawasan yang efisien menyediakan hubungan yang positif antara kepemilikan institusi dengan kinerja keuangan perusahaan. Kepemilikan institusi juga dapat meningkatkan kualitas laba yang dilaporkan dengan menekan kecenderungan manajemen untuk memanfaatkan discretionary dalam laporan keuangan (Muid, 2009).

Dengan demikian, adanya kepemilikan institusi seharusnya membuat kinerja perusahan menjadi lebih baik.

H2a : Kepemilikan institusi berpengaruh positif terhadap kualitas laba perusahaan

$H 2 b \quad$ : Kepemilikan institusi berpengaruh positif terhadap kinerja perusahaan 


\section{Komisaris Independen}

Komisaris independen memiliki tingkat independensi yang cukup tinggi. Hal ini diyakini oleh lembaga, akademisi, dan pembuat kebijakan bahwa kemandirian dari dewan komisaris independen yang bebas dari pengaruh manajemen perusahaan akan efektif dalam memantau manajemen perusahaan (Singh et al., 2015). Hal ini diyakini bahwa adanya dewan komisaris dapat memberikan pengawasan kepada manajemen sehingga manajemen bisa lebih efektif dalam menjalankan tugas dan meningkatkan kinerja perusahaan dan melaporkan laba yang lebih berkualitas.

H3a : Komisaris independen berpengaruh positif terhadap kualitas laba

$H 3 b \quad$ :Komisaris independen berpengaruh positif terhadap kinerja perusahaan

\section{Tipe Audit (Audit Type)}

Adanya perusahaan audit internasional atau yang biasa disebut "Big Four" dianggap menjadi salah satu faktor penting yang akan mempengaruhi mekanisme GCG dalam suatu perusahaan. Perusahaan audit Big 4 dipercaya dapat mengontrol perilaku oportunistik manajemen, mengurangi biaya agensi, dan meningkatkan nilai perusahaan (Aljifri dan Moustafa, 2007).

Berdasarkan pernyataan di atas, maka hipotesis yang diambil adalah sebagai berikut:

H4a : Tipe audit berpengaruh positif terhadap kualitas laba

$H 4 b \quad$ : Tipe audit berpengaruh positif terhadap kinerja perusahaan

\section{Payout Ratio}

Pembayaran dividen akan membuat perusahaan mendapatkan pemantauan yang lebih karena sering masuk ke pasar. Pembayaran dividen yang lebih tinggi dapat membatasi kebijaksanaan manajemen dalam arus kas bebas (Jensen 1986). Hal yang seperti ini diharapkan akan memberi dampak yang positif terhadap kinerja perusahaan.

H5a : Payout ratio berpengaruh positif terhadap kualitas laba

H5b : Payout ratio berpengaruh positif terhadap kinerja perusahaan

\section{Debt Ratio}


Pengaruh Kepemilikan Keluarga Dan Good Corporate Governance...

Rasio utang memiliki pengaruh campuran terhadap kinerja perusahaan (Aljifri dan Moustafa, 2007). Di satu sisi, rasio utang mungkin memberikan pengaruh positif karena mengurangi arus kas bebas dan menjadikan perusahaan lebih dipantau oleh pasar. Selain itu, adanya ancaman akan kegagalan membayar utang dapat menjadi motivasi yang efektif sehigga membuat perusahaan lebih efisien. Akan tetapi, di sisi lain, utang memberikan dampak negatif baik dari biaya kebangkrutan ataupun biaya agensi hutang.

Berdasarkan pernyataan di atas, maka hipotesis yang diambil adalah sebagai berikut:

H6a : Debt ratio memiliki pengaruh negatif terhadap kualitas laba

H6b : Debt ratio memiliki pengaruh negatif terhadap kinerja perusahaan

\section{Gambar 1}

\section{Model Penelitian Kualitas Laba}

\section{Variabel Independen}

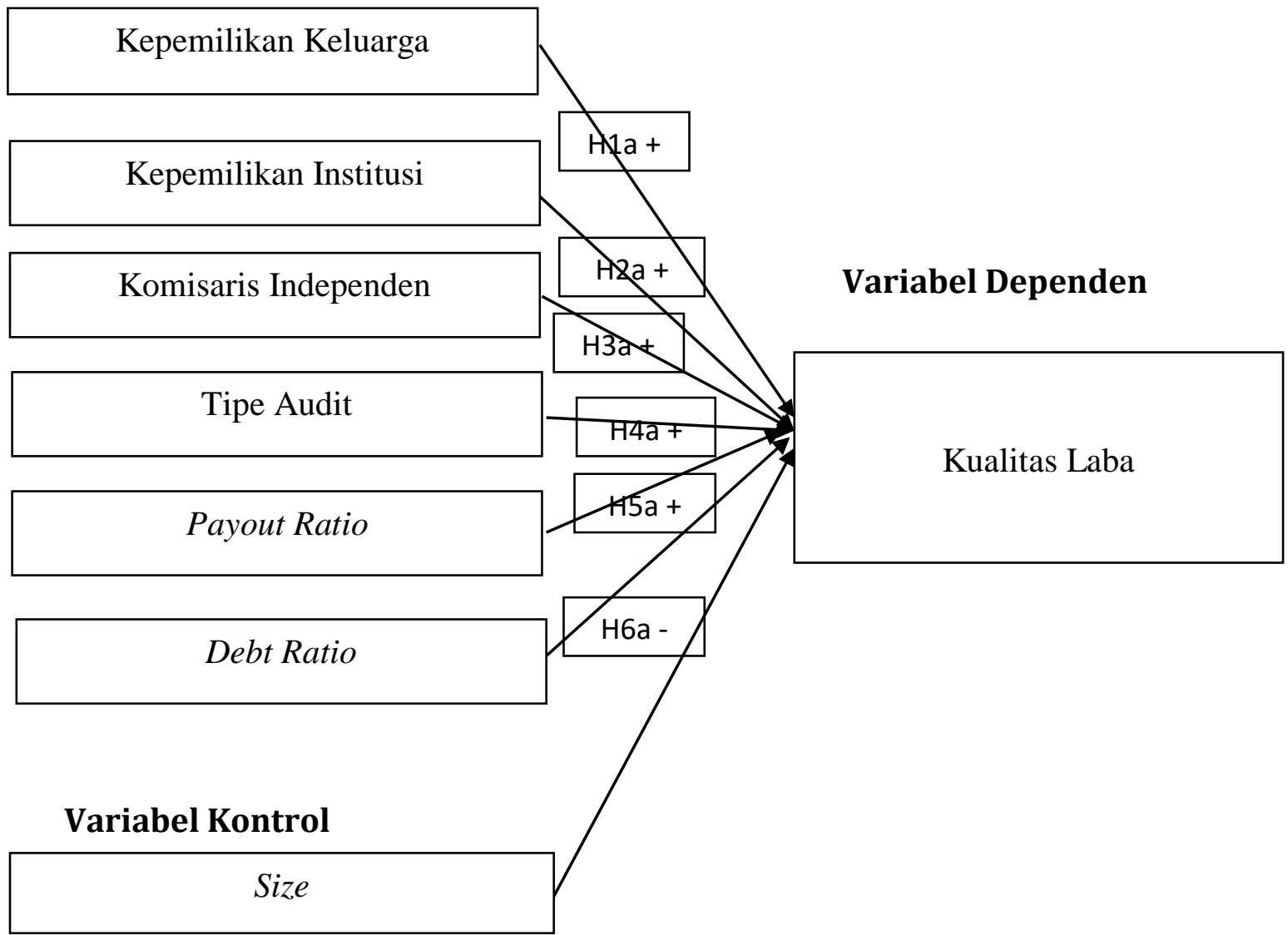


Gambar 2

\section{Model Penelitian Kinerja Perusahaan}

\section{Variabel Independen}

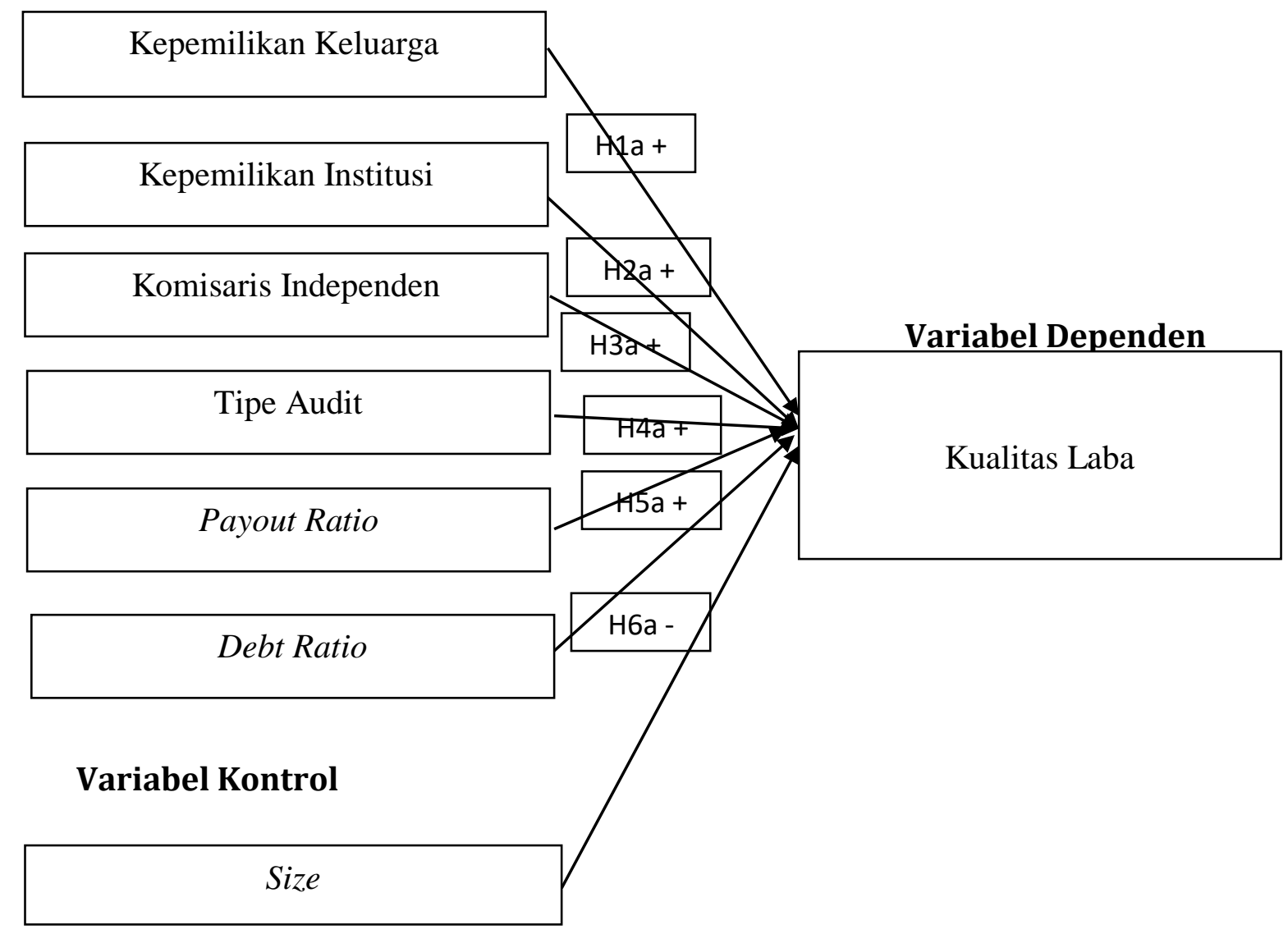

\section{METODOLOGI PENELITIAN}

\section{Populasi dan Sampel}

Populasi dalam penelitian ini adalah perusahaan-perusahaan yang sudah go public dan terdaftar di Bursa Efek Indonesia (BEI) pada tahun 2012-2014. Dari populasi tersebut akan diambil sampel penelitian dengn metode purposive sampling dengan kriteria sebagai berikut: (1) Perusahaan yang terdaftar di Bursa Efek Indonesia selama tahun 2012 sampai dengan 2014, (2) Perusahaan yang menerbitkan annual report tahun 2012 sampai dengan 2014 dan dapat diakses, (3) Perusahaan yang menyediakan semua informasi yang dibutuhkan oleh peneliti untuk mengukur variabel-variabel dalam penelitian. 
Pengaruh Kepemilikan Keluarga Dan Good Corporate Governance...

\section{Definisi Operasional dan Pengukuran}

\section{Kualitas Laba}

Bellovary et al. dalam Surifah (2010) mendefinisikan kualitas laba sebagi kemampuan laba perusahaan dalam memprediksi laba mendatang dengan mempertimbangkan stabilitas dan persistensi laba. Tidak ada ukuran pasti untuk mengukur seberapa besar kualitas laba perusahaan, yang ada hanya pendekatan yang digunakan untuk memproksikan kualitas laba tersebut sehingga ukuran laba yang digunakan satu peneliti dengan peneliti lainnya mungkin saja berbeda. Pengukuran untuk kualitas laba dalam penelitian ini diproksikan dengan discretionary accruals model Jones yang dimodifikasi (modified Jones' Model) karena dianggap lebih baik dari model lain. Rumus modified Jones' Model adalah sebagai berikut:

Langkah pertama untuk mendapatkan variable nondiscretionary accruals dan discretionary accruals adalah mencari current accruals (CA).

\section{$\mathrm{CA}_{\mathrm{it}}=\Delta($ current asset - cash $)-\Delta($ current liabilities - current maturity of long term debt)}

Selanjutnya yitu menghitung nilai current accruals sebagai berikut:

$$
\mathrm{CA}_{\text {it }} / \mathrm{TA}_{\mathrm{it}-1}=\mathrm{a}_{0}\left(1 / \mathrm{TA}_{\mathrm{it}-1}\right)+\mathrm{a}_{1}\left(\Delta \mathrm{SAL}_{\mathrm{it}} / \mathrm{TA}_{\mathrm{it}-1}\right)+\varepsilon_{\mathrm{it}}
$$

Untuk menghitung nondiscretionary accruals (NDACC) digunakan koefisien regresi di atas (a0, a1) dengan rumus sebagai berikut:

$$
\text { NDACC }_{i t}=a_{0}\left(1 / T_{i t-1}\right)+a_{1}\left(\left(\Delta S A L_{i t}-\Delta A / R_{i t}\right) / T_{i t-1}\right)
$$

Discretionary accruals (DACC) diperoleh dari rumus sebagai berikut:

$$
\text { DACC }_{i t}=\mathrm{CA}_{\mathrm{it}} / \mathrm{TA}_{\mathrm{it}-1}-\mathrm{NDACC}_{\mathrm{it}}
$$

\section{Keterangan:}

$\mathrm{CA}_{\mathrm{it}} \quad=$ Current accruals perusahaan i pada periode $\mathrm{t}$

$\triangle \mathrm{SAL}_{\mathrm{it}} \quad=$ Perubahan penjualan bersih perusahaan i pada periode $\mathrm{t}$

NDACC $_{\text {it }} \quad=$ Non discretionary accruals perusahaan perusahaan $\mathrm{i}$ pada periode $\mathrm{t}$

$\Delta \mathrm{A} / \mathrm{R}_{\mathrm{it}} \quad=$ Perubahan piutang bersih perusahaan $\mathrm{i}$ pada periode $\mathrm{t}$

$\mathrm{TA}_{\mathrm{it}-1}=$ Total aset perusahaan $\mathrm{i}$ pada periode $\mathrm{t}-1$

DACC $_{\text {it }}=$ Discretionary accruals perusahaan I pada periode $t$ 


\section{Kinerja Perusahaan}

Kinerja perusahaan merupakan cerminan dari kemampuan perusahaan dalam mengalokasikan sumber daya yang dimilikinya. Kinerja perusahaan dalam penelitian diproksikan dengan nilai perusahaan. Nilai perusahaan diukur dengan menggunakan Tobin's Q. Rasio Tobin's Q dapat dihitung dengan menggunakan rumus sebagai berikut:

$$
\mathbf{Q}=\frac{(E M V+D)}{T A}
$$

Q

EMV (Equity Market Value)

$\mathrm{D}$

TA
: Nilai perusahaan

: Nilai pasar ekuitas; EMV merupakan hasil perkalian dari harga saham penutupan (close price) akhir tahun dengan jumlah saham yang beredar pada akhir tahun

: Nilai buku dari total utang

: Nilai buku dari total aset

\section{Kepemilikan Keluarga}

Menurut Wirawan dan Diyanti (2014), kepemilikan keluarga merupakan keseluruhan individu dan perusahaan yang kepemilikannya tercatat (kepemilikan 5\% ke atas wajib dicatat), kecuali perusahaan publik, negara, institusi keuangan (lembaga investasi, reksa dana, asuransi, bank, atau dana pensiun) dan publik (yang kepemilikannya tidak wajib dicatat). Penelusuran kepemilikan keluarga dapat dilakukan dengan dua acara yaitu melihat nama dewan direksi dan dewan komisaris (Harijono, 2013).

$$
\text { Jumlah Kepemilikan Keluarga }=\frac{\text { Jumlah saham yang dimiliki keluarga }}{\text { Jumlah total saham }} \times 100 \%
$$

\section{Kepemilikan Institusi}

Struktur kepemilikan institusi merupakan jumlah saham beredar yang dimiliki oleh institusi atau badan. Institusi yang dimaksud adalah badan usaha lain baik dalam negeri maupun luar negeri, lembaga keuangan, yayasan, serta pemerintah.

Struktur kepemilikan institusi diukur dengan menggunakan rumus:

$$
\text { Jumlah Kepemilikan Institusi }=\frac{\text { Jumlah saham yang dimiliki institusi }}{\text { Jumlah total saham }} \times 100 \%
$$


Pengaruh Kepemilikan Keluarga Dan Good Corporate Governance...

\section{Komisaris Independen}

Menurut UU No. 40 tahun 2007, komisaris independen adalah anggota dewan komisaris yang tidak memiliki hubungan kepengurusan, kepemilikan saham, dan/atau hubungan keluarga lainnya dengan anggota dewan komisaris lainnya, direksi dan/atau pemegang saham pengendali atau hubungan dengan bank, yang dapat mempengaruhi kemampuannya untuk bertindak independen.

Komisaris independen diukur dengan menggunakan rasio komisaris independen yaitu:

Proporsi Komisaris Independen =

$$
\frac{\text { Iumlah komisaris idependen }}{\text { Jumlah komisaris }} \times 100 \%
$$

\section{Tipe Audit}

Dalam penelitian ini variabel tipe audit diukur dengan menggunakan variabel dummy. Penelitian Aljifri dan Moustafa (2007) mengukur tipe audit dengan variabel dummy, dimana memberi nilai 1 untuk perusahaan audit Big 4 dan nilai 0 untuk perusahaan audit di luar Big 4. Penelitian ini akan menggunakan pengukuran yang sama dengan penelitian Aljifri dan Moustafa (2007).

\section{Payout Ratio}

Payout ratio adalah proporsi pendapatan yang dibayarkan sebagai dividen kepada para pemegang saham, biasanya dinyatakan sebagai persentase. Payout ratio juga dapat dinyatakan sebagai proporsi arus kas. Pengukuran payout ratio pada penelitian ini menggunakan variabel dummy, yaitu 1 untuk perusahaan yang membagikan dividen dan 0 untuk perusahaan yang tidak membagikan dividen.

\section{Debt Ratio}

Debt ratio merupakan rasio total utang terhadap total aktiva. Rasio ini digunakan untuk mengukur persentase dari dana yang diberikan oleh kreditor (Brigham dan Houston, 2012: 103). Rumus perhitungan dari debt ratio adalah sebagai berikut:

$$
\text { Debt ratio }=\frac{\text { Total utang }}{\text { Total aktiva }}
$$

\section{Variabel Kontrol}

Variabel kontrol adalah variabel yang dikendalikan atau dibuat konstan sehingga pengaruh variabel independen terhadap dependen tidak dipengaruhi oleh faktor luar yang 
tidak diteliti (Sugiyono, 2012). Variabel kontrol dalam penelitian ini adalah ukuran perusahaan. Ukuran perusahaan merupakan total aset perusahaan yang dalam penelitian ini diproksikan dengan log total asset.

\section{Metode Analisis Data}

Metode analisis data yang digunaka dalam penelitian ini adalah model analisa regresi. Analisa regresi digunakan untuk mengukur kekuatan hubungan antara dua variabel atau lebih dan menunjukkan arah hubungan antara variabel dependen dengan variabel independen (Ghozali, 2013: 96).

Penelitian ini menggunakan software SPSS (Statistical Package for Social Science) versi 21.0 sebagai alat regresi model formulasi untuk mempermudah analisa data dan uji hipotesis. Penelitian ini menggunakan analisis regresi berganda yang terlebih dahulu dilakukan pegujian asumsi klasik yang terdiri dari uji normalitas, uji heteroskedastisitas, dan uji multikolinearitas untuk menguji kualitas data. Kemudian, untuk pengujian hipotesis dilakukan setelah uji kualitas data.

\section{HASIL DAN DISKUSI}

Setelah seluruh perusahaan pada tahun 2012 sampai dengan 2014 dikumpulkan dan dipilih sesuai dengan kriteria, maka dapat ditentukan jumlah perusahaan yang dipilih menjadi sampel dalam penelitian berjumlah 207 sampel. Akan tetapi sebanyak 54 sampel merupakan outlier pada model pertama dan 70 sampel merupakan outlier pada model kedua sehingga dihapuskan dari pengolahan data.

Tabel 1

Pemilihan Sampel

\begin{tabular}{|c|c|c|}
\hline \multirow{2}{*}{ Kriteris Sampel } & \multicolumn{2}{|c|}{ Jumlah } \\
\cline { 2 - 3 } & Kualitas Laba & $\begin{array}{c}\text { Kinerja } \\
\text { Perusahaan }\end{array}$ \\
\hline $\begin{array}{c}\text { Jumlah perusahaan yang listing di BEI tahun } \\
\text { 2012 sampai 2014 }\end{array}$ & 1458 & 1458 \\
\hline $\begin{array}{c}\text { Jumlah perusahaan yang tidak sesuai dengan } \\
\text { kriteria }\end{array}$ & 1251 & 1251 \\
\hline Data Outlier & 54 & 70 \\
\hline Jumlah perusahaan yang menjadi sampel & 153 & 137 \\
\hline
\end{tabular}


Pengaruh Kepemilikan Keluarga Dan Good Corporate Governance...

\section{Statistik Deskriptif}

Tabel 2

Statistik Deskriptif Model Kualitas Laba

\begin{tabular}{lrrrrr}
\hline & N & $\begin{array}{c}\text { Minimu } \\
\text { m }\end{array}$ & Maximum & Mean & Std. Deviation \\
\hline Kep_Kel & 153 & 0,06 & 0,87 & 0,3776 & 0,19902 \\
Kep_Inst & 153 & 0,01 & 0,93 & 0,2935 & 0,22345 \\
Komp_Indp & 153 & 0,25 & 0,67 & 0,3787 & 0,09567 \\
Tipe_Audit & 153 & 0,00 & 1,00 & 0,4641 & 0,50034 \\
Payout_Ratio & 153 & 0,00 & 1,00 & 0,5425 & 0,49983 \\
Debt_Ratio & 153 & 0,00 & 0,87 & 0,4184 & 0,19272 \\
Size & 153 & 10,87 & 13,91 & 12,301 & 0,66120 \\
DACC & 153 & 4,40 & 4,81 & 4,6390 & 0,08603 \\
Valid N & 153 & & & & \\
(listwise) & & & & & \\
\hline
\end{tabular}

Sumber: Data Diolah, 2016

Berdasarkan hasil uji statistik deskriptif di atas maka dapat dilihat bahwa sampel yang digunakan dalam penelitian model kedua ini berjumlah 153 sampel. Tabel tersebut menggambarkan mengenai variabel kepemilikan keluarga yang memiliki nilai minimum sebesar 0,06 dan nilai maksimum 0,87. Nilai rata-rata sebesar 0,3776 dan standar deviasi 0,19902. Variabel kepemilikan institusi memiliki nilai minimum 0,01 dan nilai maksimum 0,93 . Nilai rata-rata sebesar 0,2935 dan standar deviasi sebesar 0,22345 . Variabel komisaris independen memiliki nilai minimum 0,25 dan nilai maksimum 0,67 nilai rata-rata sebesar 0,3787 dan standar deviasi sebesar 0,09567. Variabel tipe audit memiliki nilai minimum 0 yang berarti perusahaan diaudit oleh KAP non big four dan nilai maksimum 1 yang berarti diaudit oleh KAP big four. Nilai rata-rata sebesar 0,5425 dan standar deviasi sebesar 0,50034. Variabel payout ratio memiliki nilai minimum 0 yang berarti perusahaan tidak membagikan dividen dan maksimum 1 yang berarti perusahaan yang membagikan dividen. Nilai rata-rata sebesar 0,5425 dan standar deviasi sebesar 0,49983. Variabel debt ratio memiliki nilai minimum 0 dan nilai maksimum 0,87 . Nilai rata-rata sebesar 0,4184 dan standar deviasi sebesar 0,19272. Hasil pengujian variabel DACC memiliki nilai 
minimum 4,40 dan nilai maksimum 4,81. Nilai rata-rata sebesar 0,4184 dan standar deviasi sebesar 0,19272 .

Tabel 3

Statistik Deskriptif Model Kinerja Perusahaan

\begin{tabular}{llrrrr}
\hline & N & Minimum & Maximum & Mean & Std. Deviation \\
\hline Kep_Kel & 137 & 0,06 & 0,90 & 0,3745 & 0,22442 \\
Kep_Inst & 137 & 0,00 & 0,81 & 0,3047 & 0,23380 \\
Tipe_Audit & 137 & 0,00 & 1,00 & 0,4015 & 0,49199 \\
Payout_Ratio & 137 & 0,00 & 1,00 & 0,5693 & 0,49699 \\
Debt_Ratio & 137 & 0,10 & 0,98 & 0,4767 & 0,20710 \\
Kom_Indp & 137 & 0,25 & 0,67 & 0,3817 & 0,09656 \\
Size & 137 & 10,98 & 13,81 & 12,2180 & 0,62945 \\
Kinerja & 137 & 0,57 & 1,66 & 1,0530 & 0,27871 \\
Valid N (listwise) & 137 & & & & \\
\hline
\end{tabular}

Sumber: Data Diolah, 2016

Berdasarkan hasil uji statistik deskriptif di atas maka dapat dilihat bahwa sampel yang digunakan dalam penelitian model kedua ini berjumlah 137 sampel. Tabel tersebut juga menggambarkan variabel kepemilikan keluarga dengan nilai minimum 0,06 dan nilai maksimum 0,90. Nilai rata-rata sebesar 0,3745 dan standar deviasi sebesar 0,22442. Variabel kepemilikan institusi memiliki nilai minimum 0 dan nilai maksimum 0,81. Nilai rata-rata sebesar 0,3047 dan standar deviasi sebesar 0,23380. Variabel tipe audit memiliki nilai minimum 0 yang dimiliki oleh perusahaan yang diaudit oleh KAP non big four dan nilai maksimum 1 yang berarti perusahaan yang diaudit oleh KAP big four. Nilai rata-rata sebesar 0,4015 dan standar deviasi sebesar 0,49199. Variabel payout ratio memiliki nilai minimum 0 pada perusahaan-perusahaan yang tidak membagikan dividend an nilai maksimum satu yaitu perusahaan-perusahaan yang membagikan dividen. Nilai rata-rata sebesar 0,5693 dan standar deviasi sebesar 0,49699. Variabel debt ratio memiliki nilai minimum 0,10 dan nilai maksimum 0,98. Nilai rata-rata sebesar 0,4767 dan standar deviasi sebesar 0,20710. Variabel komisaris independen memiliki nilai minimum 0,25 dan nilai maksimum 0,67. Nilai rata-rata sebesar 0,3817 dan standar deviasi sebesar 0,09656. 
Pengaruh Kepemilikan Keluarga Dan Good Corporate Governance...

Variabel kinerja perusahaan memiliki nilai minimal 0,57 dan nilai maksimum 1,66. Nilai rata-rata sebesar 1,0530 dan standar deviasi sebesar 0,27871.

\section{Pengujian Hipotesis}

Tabel 4

Hasil Uji Koefisien Determinasi ( $\left.\mathbf{R}^{2}\right)$ Kualitas Laba

\begin{tabular}{lcrrr}
\hline Model & R & R Square & $\begin{array}{c}\text { Adjusted R } \\
\text { Square }\end{array}$ & $\begin{array}{r}\text { Std. Error of } \\
\text { the Estimate }\end{array}$ \\
\hline 1 & 0,674 & 0,454 & 0,428 & 0,06507 \\
\hline
\end{tabular}

Dependent Var: DACC

Sumber: Data Diolah, 2016

Berdasarkan tabel di atas, dapat dilihat bahwa nilai adjusted R square sebesar 0,428 atau 42,8\%. Hal ini berarti 42,8\% dari variabel dependen yaitu DACC dapat dijelaskan oleh variabel independen yaitu kepemilikan keluarga, kepemilikan institusi, komisaris independen, tipe audit, payout ratio dan debt ratio. Sisanya sebesar 57,2\% dipengaruhi oleh faktor lain yang tidak termasuk dalam model analisis.

\section{Tabel 5}

Hasil Uji Statistik F Model Kinerja Perusahaan

\begin{tabular}{lrrrr}
\hline Model & R & R Square & $\begin{array}{c}\text { Adjusted R } \\
\text { Square }\end{array}$ & $\begin{array}{r}\text { Std. Error of } \\
\text { the Estimate }\end{array}$ \\
\hline 1 & 0,513 & 0,263 & 0,223 & 0,24566 \\
\hline $\begin{array}{l}\text { Dependen Var: Kinerja } \\
\text { Sumber: Data Diolah, 2016 }\end{array}$ & & \\
Sumber & &
\end{tabular}

Berdasarkan tabel di atas, dapat dilihat bahwa nilai adjusted R square sebesar 0,223 atau 22,3\%. Hal ini berarti 22,3\% dari variabel dependen yaitu Kinerja Perusahaan yang diproksikan dengan Tobin's Q dapat dijelaskan oleh variabel independen yaitu kepemilikan keluarga, kepemilikan institusi, komisaris independen, tipe audit, payout ratio dan debt ratio. Sisanya sebesar 77,7\% dipengaruhi oleh faktor lain yang tidak termasuk dalam model analisis.

\section{Tabel 6}

\section{Hasil Uji Statistik t Model Kualitas Laba}

\begin{tabular}{ccccc}
\hline $\begin{array}{c}\text { Unstandardized } \\
\text { Coefficients }\end{array}$ & $\begin{array}{c}\text { Standardized } \\
\text { Coefficients } \\
\text { B }\end{array}$ Std. Error & Beta & T & Sig. \\
\hline
\end{tabular}




\begin{tabular}{lrrrrr}
\hline (Constant) & 3,598 & 0,124 & & 29,116 & 0,000 \\
Kep_Kel & 0,029 & 0,033 & 0,066 & 0,862 & 0,390 \\
Kep_Inst & $-0,013$ & 0,030 & $-0,034$ & $-0,438$ & 0,662 \\
Komp_Indp & 0,012 & 0,057 & 0,013 & 0,203 & 0,840 \\
Tipe_Audit & 0,005 & 0,012 & 0,027 & 0,377 & 0,707 \\
Payout_Rati & 0,007 & 0,011 & 0,039 & 0,598 & 0,551 \\
o & 0,084 & 0,028 & 0,188 & 3,022 & 0,003 \\
Debt_Ratio & 0,080 & 0,010 & 0,618 & 8,399 & 0,000 \\
Size & & & & & \\
\hline
\end{tabular}

Dependent Var: DACC

Sumber: Data Diolah, 2016

Hasil pengolahan data dengan software SPSS untuk model kualitas laba di atas maka didapatkan persamaan regresi sebagai berikut:

$$
\begin{aligned}
\text { DACC }= & \text { 3,598 }+ \text { 0,029Kep_Kel }- \text { 0,013Kep_Inst + 0,012Kom_Ind + 0,005Tipe_Audit + } \\
& \text { 0,007Payout }+ \text { 0,084Debt }+ \text { 0,080Size }
\end{aligned}
$$

Tabel 7

\begin{tabular}{|c|c|c|c|c|c|}
\hline \multirow[t]{2}{*}{ Variabel } & \multicolumn{2}{|c|}{$\begin{array}{l}\text { Unstandardized } \\
\text { Coefficients }\end{array}$} & \multirow{2}{*}{$\begin{array}{l}\text { Standardized } \\
\text { Coefficients } \\
\text { Beta }\end{array}$} & \multirow[t]{2}{*}{$\mathrm{T}$} & \multirow[t]{2}{*}{ Sig. } \\
\hline & B & Std. Error & & & \\
\hline Konstan & $-1,244$ & 0,548 & & $-2,271$ & 0,025 \\
\hline Kep_Kel & 0,058 & 0,127 & 0,046 & 0,454 & 0,650 \\
\hline Kep_Inst & 0,292 & 0,126 & 0,245 & 2,316 & 0,022 \\
\hline Tipe_Audit & $-0,119$ & 0,053 & $-0,211$ & $-2,261$ & 0,025 \\
\hline Payout_Ratio & 0,201 & 0,044 & 0,358 & 4,538 & 0,000 \\
\hline Debt_Ratio & $-0,144$ & 0,110 & $-0,107$ & $-1,307$ & 0,193 \\
\hline Kom_Indp & 0,693 & 0,236 & 0,240 & 2,937 & 0,004 \\
\hline Size & 0,157 & 0,043 & 0,356 & 3,631 & 0,000 \\
\hline
\end{tabular}

Hasil Uji Statistik t Model Kinerja Perusahaan

Dependen Var: Kinerja

Sumber: Data Diolah, 2016

Hasil pengolahan data dengan software SPSS untuk model kinerja perusahaan di atas maka didapatkan persamaan regresi sebagai berikut:

Kinerja $=-1,244+0,058 K e{ }_{-}$Kel + 0,292Kep_Inst + 0,693Kom_Ind - 0119Tipe_Audit + 0,201Payout - 0,144Debt + 0,157Size 
Pengaruh Kepemilikan Keluarga Dan Good Corporate Governance...

\section{Hipotesis pertama (H1a): Kepemilikan keluarga memiliki pengaruh positif}

terhadap kualitas laba. Hasil pengujian regresi menunjukkan nilai t-hitung sebesar 0,862 dengan signifikansi 0,390. Nilai signifikansi tersebut di atas 0,05 sehingga hipotesis pertama (H1a) ditolak. Hasil ini bertolak belakang dengan penelitian Andayani et al. (2014) yang menunjukkan bahwa kepemilikan keluarga berpengaruh positif terhadap kualitas laba. Tidak adanya pengaruh kepemilikan keluarga terhadap kualitas laba dimungkinkan karena agency problem pada perusahaan di Indonesia tidak kuat. Selain itu, perusahaan keluarga di Indonesia meruapakan perusahaan dengan skala yang cukup besar sehingga akan cenderung mematuhi aturan-aturan seperti perusahaan publik pada umumnya ataupun karena sistem perusahaan berjalan sama saja antara perusahaan keluarga dengan non keluarga.

Hipotesis kedua (H1b): Kepemilikan keluarga memiliki pengaruh positif terhadap kinerja perusahaan. Hasil pengujian regresi menunjukkan nilai t-hitung sebesar 0,454 dengan signifikansi 0,650. Nilai signifikansi tersebut di atas 0,05 sehingga hipotesis kedua (H1b) ditolak. Hasil tersebut bertolak belakang dengan penelitian Andayani et al. (2014); Muttakin et al. (2014); Mani dan Lakhal (2015) yang menunjukkan bahwa kepemilikan keluarga memiliki pengaruh yang positif terhadap kinerja perusahaan. Akan tetapi, hasil dalam penelitian ini konsisten dengan penelitian yang dilakukan oleh Rouyer (2016) yang menunjukkan bahwa kepemilikan keluarga tidak mempunyai pengaruh terhadap kinerja perusahaan. Salah satu penyebab kepemilikan keluarga tidak berpengaruh secara signifikan dalam penelitian ini adalah bisnis keluarga beroperasi seperti bisnis lain pada umumnya. Sampel dari penelitian ini menggunakan perusahaan besar dimana hal ini membuat perusahaan tersebut harus mematuhi peraturan yang sama dalam hal audit ataupun peraturan lain sehingga keputusan bisnis yang diambil akan lebih rasional dan dibuat oleh orang yang bertanggung jawab baik pihak keluarga atau bukan.

Hipotesis ketiga (H2a): Kepemilikan institusi berpengaruh positif terhadap kualitas laba perusahaan. Hasil pengujian regresi menunjukkan nilai t-hitung sebesar 0,438 dengan signifikansi 0,662. Nilai signifikansi tersebut di atas 0,05 sehingga hipotesis ketiga ditolak. Hasil penelitian ini konsisten dengan penelitian Yushita et al. (2013) dan bertolak belakang dengan penelitian Muid (2009). Kepemilikan institusi diharapkan dapat 
menjadi salah satu unsur eksternal yang dapat mengawasi kinerja manajemen sehingga meminimalisir tindakan oportunistik dari manajer. Perbedaan hasil penelitian ini dengan hipotesis yang diajukan dimungkinkan karena tingkat partisipasi dari pemegang saham institusi di internal perusahaan baik dalam monitoring maupun pencegahan potensi konflik yang terjadi masih sangat minim.

Hipotesis keempat (H2b): Kepemilikan institusi berpengaruh positif terhadap kinerja perusahaan. Hasil pengujian regresi menunjukkan nilai t-hitung sebesar 2,316 dengan signifikansi 0,022. Nilai signifikansi tersebut di bawah 0,05 sehingga hipotesis diterima. Hasil ini tidak sesuai dengan penelitian Navissi dan Naiker (2006) dan Mahaputeri dan Yadnyana (2014) dan konsisten dengan penelitian Tsai dan Tung (2014). Kepemilikan institusi menjadi salah satu mekanisme pengendalian eksternal yang digunakan untuk meminimalisir terjadinya tindakan berlebihan oleh manajer (Mahaputeri dan Yadnyana, 2014). Adanya pihak institusional akan mampu mengoptimalkan pengawasan kepada manajemen dengan memonitoring setiap keputusan yang diambil. Hal ini memungkinkan institusi untuk menekan sikap oportunistik manajemen sehingga manajer dapat meningkatkan kinerjanya yang akan berimbas pada kinerja perusahaan yang semakin baik pula.

Hipotesis kelima (H3a): Komisaris independen berpengaruh positif terhadap kualitas laba perusahaan. Hasil pengujian regresi menunjukkan nilai t-hitung sebesar 0,203 dengan signifikansi 0,840. Nilai signifikansi tersebut di atas 0,05 sehingga hipotesis kelima ditolak. Jika dilihat dari hasil penelitian ini sesuai dengan teori stewardship dimana komisaris independen dijelaskan sebagai pihak luar yang tidak mengetahui informasi perusahaan secara spesifik dan memiliki kepedulian yang lebih rendah daripada komisaris ataupun direktur dalam perusahaan (Allahyaribeik dan Rohi, 2015). Hal ini menyebabkan pengawasan yang dilakukan tidak efektif sehingga keputusan yang dibuat tidak dapat meningkatkan kualitas laba yang dilaporkan. Selain itu, kemungkinan rendahnya praktek corporate governance yang menjadikan komisaris independen hanya sebagai pemenuhan kewajiban atas regulasi yang ada sehingga keberadaannya tidak dapat meningkatkan efektivitas monitoring yang harusnya dijalankan.

Hipotesis keenam (H3b): Komisaris independen berpengaruh positif terhadap kinerja perusahaan. Hasil pengujian regresi menunjukkan nilai t-hitung sebesar 2,937 
Pengaruh Kepemilikan Keluarga Dan Good Corporate Governance...

dengan signifikansi 0,004. Nilai signifikansi tersebut di bawah 0,05 sehingga hipotesis diterima. Hasil ini konsisten dengan penelitian Wang dan Oliver (2009) dan bertolak belakang dengan penelitian Bhattacharya (2015), Prabowo dan Simpson (2011), Gaur et al. (2015) serta Arora dan Sharma (2016). Alasan komisaris independen berpengaruh positif terhadap kinerja perusahaan karena komisaris independen telah memaksimalkan perannya dalam melakukan pengawasan sebagaimana mestinya kepada manajemen sehingga manajemen bisa lebih efektif dalam meningkatkan kinerja perusahaan. Hal tersebut di atas juga semakin diperkuat oleh penelitian yang dilakukan oleh Beasly (1996) yang menemukan bahwa perusahaan yang tidak melakukan kecurangan memiliki persentase direktur luar yang lebih besar daripada perusahaan yang melakukan kecurangan. Hal tersebut membuktikan bahwa semakin besar jumlah komisaris independen dalam suatu perusahaan akan meminimalisir perusahaan dalam melakukan kecurangan sehingga kinerja perusahaan bagus.

Hipotesis ketujuh (H4a): Tipe audit berpengaruh positif terhadap kualitas laba perusahaan. Hasil pengujian regresi menunjukkan nilai t-hitung sebesar 0,377 dengan signifikansi 0,707. Nilai signifikansi tersebut di atas 0,05 sehingga hipotesis ketujuh ditolak. Hasil ini konsisten dengan penelitian Al-dhamari dan Ismail (2015) dan Siallagan (2006). Tidak adanya pengaruh ukuran KAP kemungkinan terjadi karena kemungkinan perusahaan yang memiliki kendala dalam perusahaannya akan cenderung memilih diaudit oleh KAP yang memiliki kemampuan rendah dalam mengaudit sehingga adanya kualitas laba yang rendah atau bahkan manajemen laba tidak terdeteksi.

Hipotesis kedelapan (H4b): Tipe audit berpengaruh positif terhadap kinerja perusahaan. Hasil pengujian regresi menunjukkan nilai t-hitung sebesar -2,261 dengan signifikansi 0,025. Nilai signifikansi tersebut di bawah 0,05 sehingga hipotesis diterima. Berdasarkan hasil penelitaian yang telah dilakukan menunjukan bahwa tipe audit berpengaruh terhadap kinerja perusahaan dengan arah negatif. KAP Big 4 yang berpengaruh negatif terhadap kinerja perusahaan kemungkinan penyebabnya karena kurang ketatnya pengawasan regulator terhadap jasa audit yang dilakukan oleh KAP Big 4 akibat ketergantungan pasar terhadap KAP Big 4 (Nindita dan Siregar, 2012). Ketergantungan seperti ini muncul karena keunggulan KAP Big 4 dalam hal kemampuannya 
memberikan jasa audit yang berkualitas kepada perusahaan-perusahaan besar dibandingkan dengan KAP Non Big 4. Selain itu, rendahnya kompetisi KAP besar dengan jumlah klien yang banyak menyebabkan KAP besar merasa pada area yang aman dan cenderung kurang memperhatikan kualitas auditnya sehingga memungkinkan penurunan kualitas audit yang akhirnya tidak dapat mendeteksi secara baik bagaimana kinerja perusahaan yang diaudit (Nindita dan Siregar, 2012).

Hipotesis kesembilan (H5a): Payout ratio berpengaruh positif terhadap kualitas laba perusahaan. Hasil pengujian regresi menunjukkan nilai t-hitung sebesar 0,598 dengan signifikansi 0,551. Nilai signifikansi tersebut di atas 0,05 sehingga hipotesis kesembilan ditolak. Hasil ini bertolak belakang dengan penelitian Sirait dan Siregar (2013). Dividen diyakini dapat digunakan menjadi suatu indikator dari kualitas laba (Malkiel, 2003). Dividen yang dibayarkan menjadi indikator yang lebih baik dari kualitas laba dibandingkan dengan seberapa banyak dividen yang diberikan (Sirait dan Siregar, 2013). Hal ini dikarenakan pembayaran dividen yang konsisten menunjukkan adanya keuntungan masa depan yang lebih potensial sehingga lebih menjamin keberlangsungan dari perusahaan. Akan tetapi pada perusahaan keluarga, kepemilikan saham dominan berada ditangan keluarga yang juga menjalankan perusahaan yang biasanya akan lebih menggunakan keuntungannya untuk operasional. Jadi, ada tidaknya pembagian dividen tidak dapat dijadikan indikator apakah perusahaan memiliki kualitas laba yang potensial yang menjamin keberlangsungan untuk masa depan atau tidak.

Hipotesis kesepuluh (H5b): Payot ratio berpengaruh positif terhadap kinerja perusahaan. Hasil pengujian regresi menunjukkan nilai t-hitung sebesar 4,538 dengan signifikansi 0,000. Nilai signifikansi tersebut di bawah 0,05 sehingga diterima. Hasil ini konsisten dengan penelitian yang dilakukan oleh Isshaq et al. (2009). Jika dilihat dari agency theory, pembagian dividen dapat dijadikan sebagai salah satu cara untuk meminimalisir konflik agensi yang terjadi antara manajer dan pemegang saham (Sirait dan Siregar, 2014). Selain itu, pembagian dividen membuat pasar lebih mengawasi manajer dan kinerja sehingga manajer akan cenderung untuk meningkatkan kinerjanya sehingga berdampak positif terhadap kinerja perusahaan. Pembagaian dividen juga menjadi salah satu cara yang dilakukan manajemen untuk menjalin komunikasi yang lebih baik dengan pemegang saham untuk menunjukkan bagaimana kinerjanya selama ini. 
Pengaruh Kepemilikan Keluarga Dan Good Corporate Governance...

Hipotesis kesebelas (H6a): Debt ratio berpengaruh negatif terhadap kualitas

laba perusahaan. Hasil pengujian regresi menunjukkan nilai t-hitung sebesar 3,022 dengan signifikansi 0,003. Nilai signifikansi tersebut di bawah 0,05 sehingga hipotesis diterima dengan hubungan positif. Hasil ini bertolak belakang dengan penelitian yang dilakukan oleh Sadiah dan Priyadi (2015). Perusahaan yang memiliki utang lebih banyak akan sering menggunakan akrual dalam meningkatkan laba, sehingga diprediksi tingkat utang akan memiliki hubungan yang positif dengan discretionary accrual (Francis dan Yu, 2009). Debt ratio yang tinggi juga bisa menjadi indikasi bahwa perusahaan sedang mengalami kesulitan keuangan sehingga kualitas laba yang dihasilkan perusahaan rendah.

Hipotesis kedua belas (H6b): Debt ratio memiliki pengaruh negatif terhadap kinerja perusahaan. Hasil pengujian regresi menunjukkan nilai t-hitung sebesar -1,307 dengan signifikansi 0,193. Nilai signifikansi tersebut di atas 0,05 sehingga hipotesis kedua belas ditolak. Hasil ini berbeda dengan penelitian yang dilakukan oleh Binangkit (2014). Debt ratio adalah ukuran yang dipakai dalam menganalisis laporan keuangan untuk memperlihatkan besarnya jaminan yang tersedia untuk kreditor (Hendri, 2015). Tidak berpengaruhnya debt ratio terhadap kinerja perusahaan dikarenakan perusahaan yang dijadikan sampel merupakan perusahaan kelaurga, sehingga tingkat debt ratio bukanlah menjadi hal utama bagi investornya dalam membuat keputusan investasi.

\section{SIMPULAN, KETERBATASAN, DAN IMPLIKASI}

Penelitian ini bertujuan untuk menguji pengaruh kepemilikan keluarga dan Good Corporate Governance (GCG) terhadap kualitas laba dan kinerja perusahaan. Penelitian dilakukan dengan dua model yaitu model kualitas laba dan model kinerja perusahaan. Sampel yang digunakan dalam penelitian sebanyak 153 untuk menguji model kualitas laba dan 137 sampel untuk menguji model kinerja perusahaan. Hasil penelitian untuk model kualitas laba adalah sebagai berikut: (1) Secara bersama-sama kepemilikan keluarga, kepemilikan institusi, komisaris independen, tipe audit, payout ratio, dan debt ratio berpengaruh terhadap kualitas laba dan kinerja perusahaan, (2) Debt ratio berpengaruh dengan hubungan negatif terhadap kualitas laba yang diproksikan dengan DACC, (3) Kepemilikan keluarga, kepemilikan institusi, komisaris independen, tipe audit, dan payout ratio tidak berpengaruh terhadap kualitas laba. 
Hasil penelitian untuk model kinerja perusahaan menunjukkan bahwa: (1) Kepemilikan institusi, komisaris independen, dan payout ratio berpengaruh positif terhadap kinerja perusahaan sedangkan tipe audit berpengaruh negatif terhadap kinerja perusahaan, (2) Kepemilikan keluarga dan debt ratio tidak berpengaruh terhadap kinerja perusahaan.

Beberapa keterbatasan dan kelemahan yang turut mempengaruhi hasil dari penelitian dan perlu menjadi bahan revisi pada penelitian selanjutnya adalah: (1) Jumlah sampel yang digunakan hanya sebatas 3 tahun pengamatan yaitu 2012 sampai 2014 sehingga hasil penelitian belum dapat digeneralisir, (2) Variabel independen yang digunakan masih menunjukkan pengaruh yang relatif kecil sehingga diperlukan variabel independen lain yang dapat menjelaskan variabel dependen, (3) Kepemilikan keluarga dalam penelitian ini hanya menggunakan besarnya jumlah presentasi kepemilikannya saja, tetapi tidak meneliti mengenai regenerasi kepemimpinan dari perusahaan tersebut yang biasanya menjadi salah satu karakteristik dari perusahaan keluarga, (4) Perusahaan keluarga yang dijadikan sampel dalam penelitian ini hanya perusahaan yang menjelaskan secara rinci silsilah presentase kepemilikan keluarga dalam annual report. Sehingga ada perusahaan keluarga yang tidak masuk dalam sampel penelitian karena tidak mencantumkan presentase kepemilikan secara jelas.

Penelitian ini memberikan implikasi bagi beberapa pihak baik akademisi maupun praktisi. Bagi peneliti, penelitian ini diharapkan dapat memberikan manfaat untuk memperdalam dan memahami akuntansi keuangan, khususnya mengenai struktur kepemilikan perusahaan, tata kelola perusahaan, kualitas laba dan kinerja perusahaan keluarga serta dapat meningkatkan keilmuan peneliti. Bagi akademisi, hasil penelitian ini berguna untuk menambah referensi, wawasan dan pemahaman atas pengaruh kepemilikan keluarga dan tata kelola perusahaan terhadap kualitas laba dan kinerja perusahaan. Bagi praktisi, hasil penelitian ini dapat dijadikan sebagai pertimbangan tambahan untuk menentukan kebijakan serta mengambil keputusan yang berkaitan dengan peningkatan kualitas laba dan kinerja perusahaan. 
Pengaruh Kepemilikan Keluarga Dan Good Corporate Governance...

\section{DAFTAR PUSTAKA}

Al-Dhamari, R., dan K. N. I. Kuh Ismail. 2015. Cash Holdings, Political Connections, and Earning Quality. International Journal of Managerial Finance, Vol. 11, No. 2, Hal. 215-231.

Al-Ghamdi, M., dan Mark Rhodes. 2015. Family Ownership, Corporate Governance and Performance: Evidence from Saudi Arabia. International Journal of Economic and Finance, Vol. 7, No. 2.

Aljifri, K., dan Mohamed Moustafa. 2007. The Impact of Corporate Governance Mechanisms on the Performance of UAE Firms: An Empirical Analysis. Journal of Economic \& Administratif Sciences, Vol. 23, No. 2, Hal. 71-93.

Allahyarbeik, N dan Ali Rohi. 2015. Effect of Corporate Governance Element on Innate and Discretionary Accruals Quality. Indian Journal of Fundamental and Applied Life Science, Vol, 5, Hal. 1961-1971.

Andayani, W., Jogiyanto., Supriyadi., dan Setiyono Miharjo. 2014. Pengaruh Kepemilikan Keluarga terhadap Pengelolaan Laba dan Kinerja Perusahaan: Ditinjau dari Teori Stewardship.

Anderson, R. C., dan David M. Reeb. 2003. Founding-Family Ownership and Firm Performance: Evidence from The S\&P 500. The Journal of Finance, Vol. 58, No. 3, Hal. 1301-1328.

Ardianingsih, A., dan Komala Ardiani. 2010. Analisis Pengaruh Struktur Kepemilikan terhadap Kinerja Perusahaan. Jurnal Peta, Volume. 19, No. 2.

Arora, A., dan Chandan Sharma. 2016. Corporate Governance and Firm Performance in Developing Countries: Evidence from India. Corporate Governance, Vol 16, No. 2, Hal. 420-436. 
Astuti, A.D., Abdul Rahman., dan Sudarno. 2015. Pengaruh Kepemilikan Keluarga terhadap Kinerja Perusahaan dengan Agency Cost sebagai Variabel Moderating. Jurnal Dinamika Akuntansi, Vol. 7, No. 2, Hal. 98-108.

Bhatt, R. R., dan Sujoy Bhattacharya. 2015. Board Structure and Firm Performance in Indian IT Firms. Journal of Advances in Management Research, Vol. 12, No. 3, Hal. 232-248.

Binangkit, A.B., dan Sugeng Raharjo. 2014. Pengaruh Struktur Modal terhadap Kinerja Perusahaan dan Harga Saham pada Perusahaan Manufaktur di Bursa Efek Indonesia. Jurnal Aktual, Vol. 1, No. 2, Hal. 24-34.

Bringham, E. F., dan Joel F. Houston. 2012. Dasar-Dasar Manajemen Keuangan. Edisi Kesebelas. Jakarta: Salemba Empat.

Corstjens, M., K. Maxwell., dan L. Van der Heyden. 2004. Family Ownership and Firm Performance: Evidence from the French Stock Market. Conference on The Evolution of Corporate Governance and Family Firms. January $30^{\text {th }} \& 31^{\text {th }}$, Fontainebleau.

Darmadi, S. 2016. Ownership Concentration, Familly Control, and Auditor Choice. Asian Review of Accounting, Vol. 24, No. 1, Hal. 19-42.

Francis, J.R., dan Yu, D.M. 2009. Big 4 Office Size and Audit Quality. The Accounting Review, Vol. 8, Hal. 1521-1552.

Gaur, S., Hanoku Bathula., dan Deeksha Singh. 2015. Ownership Concentration, Board Characteristic and Firm Performance. Management Decision, Vol. 53,No. 5, Hal. 911-931.

Giovannini, R. 2010. Family Ownership, Corporate Governance and Performance of Italian Firms. Laman sumber: http://www2.unimarconi.it/DSEA/wpcontent/uploads/2010/02/Family_Ownership.pdf. Diakses pada tanggal 5 Oktober 2015.

Ghozali, I. 2013. Aplikasi Analisis Multivariat dengan Program IBM SPSS 21. Edisi Ketujuh. Semarang: Badan Penerbit Universitas Diponegoro.

Hendri, E. 2015. Pengaruh Debt To Asset Ratio (DAR), Long Term Debt To Equity Ratio (LTDER) dan Net Profit Margin (NPM) terhadap Harga Saham pada 
Pengaruh Kepemilikan Keluarga Dan Good Corporate Governance...

Perusahaan Perbankan yang Terdaftar di Bursa Efek Indonesia. Jurnal Media Wahana Ekonomika, Vol. 12, No. 2, Hal. 1-19.

Isshaq, Z., Godfred A. Bokpin., dan Josep Mensah Onumah. 2009. Corporate Governance, Ownership Structure, Cash Holdings, and Firm Value on The Ghana Stock Exchange. The Journal of Risk Finance, Vol. 10, No. 5, Hal. 488-499.

Jensen, M. C. 1986. Agency Cost of Free Cash Flow, Corporate Finance, and Takeovers. American Economic Review, Vol 76, No. 2.

Jensen, M. C., dan W. H. Meckling. 1976. Theory of The Firm: Managerial Behavior, Agency Cost and Ownership Structure. Journal of Financial Economics, Vol. 3, Hal. 305-360.

Lam, T.Y., dan Shu-kam Lee. 2012. Family Ownership, Board Committees and Firm Performance: Evidence from Hongkong. Corporate Governance, Vol. 12, No. 3, Hal. 353-366.

Latan, H. 2014. Aplikasi Analisis Data Statistik Untuk Ilmu Sosial dengan IBM SPSS. Bandung: Alfabeta.

Mahaputeri, A.A., dan I.Kt. Yadnyana. 2014. Pengaruh Struktur Kepemilikan, Kebijakan Pendanaan dan Ukuran Perusahaan pada Kinerja Perusahaan. E-Journal Akuntansi Universitas Udayana, Vol. 9, No. 1, Hal 56-68.

Malkiel, B., 2003. The Dividend Bounce, Wall Street Journal; Opinion. Laman sumber: http://online.wsj.com/article/0,SB1042077139976570304 search,00.html. Diakses pada tanggal 11 Mei 2016.

Mani, Y., dan Lassad Lakhal. 2015. Exploring the Family Effect on Firm Performance: The Impact of Internal Social Capital Dimensions on Family Firm Performance. International Journal of Enterpreneurial Behavior \& Research, Vol. 21, No. 6, Hal. 898-917.

Martinez, J. I., dan Bernhard S. Stohr. 2005. Family Ownership and Firm Performance: Evidence from Public Companies in Chile. Documento De Trabajo. Laman sumber: http://www.ese.cl/wpcontent/blogs.dir/1/files mf/1372091066DT0509.pd. Diakses pada tanggal 5 Oktober 2015. 
Masdupi, 2005. Analisis Dampak Struktur Kepemilikan pada Kebijakan Hutang dalam Mengontrol Konflik Keagenan. Jurnal Ekonomi dan Bisnis, Vol. 20, No. 1, Hal. 56-69.

McGee, T. 2013. Perspectives on family-Owned Business, Governance and Succession Planning. Delloite Growth Enterprise Services.

Muid, D. 2009. Pengaruh Mekanisme Corporate Governance terhadap Kualitas laba. Fokus Ekonomi, Vol. 4, No. 2, Hal. 94-108.

Mulyadi. 2007. Sistem Akuntansi. Jakarta: Salemba Empat.

Muttakin, M. B., Arifur Khan., dan Nava Subramaniam. 2014. Family Firms, Family Generation and Performance: Evidence from an Emerging Economy. Journal of Accounting in Emerging Economies, Vol. 4, No. 2, Hal. 197-219.

Navissi, F., dan Vic Naiker. 2006. Institutional Ownership and Corporate Value. Managerial Finance, Vol. 32, No. 3, Hal. 247-256.

Nindita, C., dan Sylvia V. Siregar. 2012. Analisis Pengaruh Ukuran Kantor Akuntan Publik terhadap Kualitas Audit di Indonesia. Jurnal Akuntansi dan Keuangan, Vol. 14, No. 2, Hal. 91-104.

Nuraeni. 2010. Pengaruh Struktur Kepemilikan Saham terhadap Kinerja Perusahaan. Laman sumber: https://core.ac.uk/download/files/379/11721586.pdf. Diakses pada 10 November 2015.

Pieper, T. M. 2003. Corporate Governance in Family Firms: A Literature Review. International Family Enterprise Research Academy Meeting, Milan.

Prabowo, M., dan John Simpson. 2011. Independent Directors and Firm Performance in Family Controlled Firms: Evidence from Indonesia. Asian Pacific Economic Literature.

Raharjo, E. 2007. Teori Agensi dan Teori Stewerdship dalam Perspektif Akuntansi. Fokus Ekonomi, Vol. 2, No. 1, Hal. 37-46.

Republik Indonesia. Undang-Undang No 40 Tahun 2007 tentang Anggaran Dasar Perseroan. Rouyer, E. 2016. Family Ownership and Busy Boards: Impact on Performance. Management Decision, Vol. 54, No. 4. 
Pengaruh Kepemilikan Keluarga Dan Good Corporate Governance...

Sadiah, H., dan M. P. Priyadi. 2015. Pengaruh Leverage, Likuiditas, Size, Pertumbuhan Laba dan IOS terhadap Kualitas Laba. Jurnal Ilmu \& Riset Akuntansi, Vol. 4, No. 5, Hal. 1-21.

Sekaran, U., dan Roger Bougie. 2013. Research Method for Business: A Skill Building Approach. United Kingdom: John Wiley \& Sons.

Siallagan, H. 2006. Mekanisme Corporate Governance, Kualitas Laba, dan Nilai Perusahaan. Simposium Nasional Akuntansi 9. 23-26 Agustus, Padang.

Sirait, F., dan Sylvia V. Siregar. 2014. Dividend Payment and earning Quality: Evidence from Indonesia. International Journal of Accounting and Information Management, Vol. 22, No. 2, Hal 103-117.

Sugiyono, 2012. Metode Penelitian Kuantitatif Kualitatif dan R\&B. Bandung: Alfabeta.

Surifah, 2010. Kualitas Laba dan Pengukurannya. Jurnal Ekonomi, Manajemen, dan Akuntansi, Vol. 8, No. 2, Hal. 31-47.

Susanto, S. 2012. Corporate Governance, Kualitas Laba, dan Biaya Ekuitas: Studi Empiris Perusahaan Manufaktur yang Terdaftar di Bursa Efek Indonesia Tahun 2009. Laman sumber: lib.ui.ac.id/file?file=digital/20297187-SSiswardika\%20Susanto.pdf. Diakses pada 2 November 2015.

Tertius, M. A., dan Yulius Jogi C. 2015. Pengaruh Corporate Governance terhadap Kinerja Perusahaan pada Sektor Keuangan. Business Accounting Review, Vol. 3, No. 1, Hal. 223-232.

Tsai, M.T., dan Wen-Hui Tung. 2014. Corporate Governance, Resources, FDI Commitment and Firm Performance Empirical Analysis of Taiwanese High-Tech Firms. Chinese Management Studies, Vol. 8, No. 3, Hal. 313-332.

Wang. Y., dan Judith Oliver. 2009. Board Composition and Firm Performance Variance: Australian Evidence. Accounting Research Journal, Vol. 22, No. 2, Hal. 196-212.

Wiranata, Y. A., dan Yetarina W. Nugrahanti. 2013. Pengaruh Struktur Kepemilikan terhadap Profitabilitas Perusahaan Manufaktur di Indonesia. Jurnal Akuntansi dan Keuangan, Vol. 15, No. 1, Hal. 15-26. 
Wirawan, W., dan Vera Diyanty. 2014. Kepemilikan Keluarga, Hubungan Politik dan Family Aligned Board terhadap Implementasi Tata Kelola Perusahaan. Simposium Nasional Akuntansi 17. 24-27 September, Lombok.

Wulandari, Tri. 2012. Analisis Pengaruh Political Connection dan Struktur Kepemilikan terhadap Kinerja Perusahaan. Skripsi. Fakultas Ekonomika dan Bisnis Universitas Diponegoro.

Yushita, A. N., Rahmawati., dan Hanung Triatmoko. 2013. Pengaruh Mekanisme Corporate Governance, Kualitas Auditor Eksternal, dan Likuiditas terhadap Kualitas Laba. Jurnal Economia, Vol. 9, No. 2, Hal. 141-155.

http://www.cnnindonesia.com/ekonomi/20150821101900-92-73523/sekitar-700perusahaan-keluarga-dunia-putar-modal-di-asia/. Diakses pada: 2 Oktober 2015. 